\title{
Fecal glucocorticoids and anthropogenic injury and mortality in North Atlantic right whales Eubalaena glacialis
}

\author{
Rosalind M. Rolland ${ }^{1, *}$, William A. McLellan ${ }^{2}$, Michael J. Moore ${ }^{3}$, Craig A. Harms ${ }^{4}$, \\ Elizabeth A. Burgess ${ }^{1}$, Kathleen E. Hunt ${ }^{1,5}$ \\ ${ }^{1}$ Anderson Cabot Center for Ocean Life, New England Aquarium, Central Wharf, Boston, MA 02110, USA \\ ${ }^{2}$ Biology and Marine Biology, University of North Carolina Wilmington, Wilmington, NC 28403, USA \\ ${ }^{3}$ Biology Department, Woods Hole Oceanographic Institution, Woods Hole, MA 02543, USA \\ ${ }^{4}$ Department of Clinical Sciences and Center for Marine Sciences and Technology, College of Veterinary Medicine, \\ North Carolina State University, Morehead City, NC 28557, USA \\ ${ }^{5}$ Present address: Center for Bioengineering Innovation, Northern Arizona University, Flagstaff, AZ 86011, USA
}

\begin{abstract}
As human impacts on marine ecosystems escalate, there is increasing interest in quantifying sub-lethal physiological and pathological responses of marine mammals. Glucocorticoid hormones are commonly used to assess stress responses to anthropogenic factors in wildlife. While obtaining blood samples to measure circulating hormones is not currently feasible for freeswimming large whales, immunoassay of fecal glucocorticoid metabolites (fGCs) has been validated for North Atlantic right whales Eubalaena glacialis (NARW). Using a general linear model, we compared fGC concentrations in right whales chronically entangled in fishing gear $(\mathrm{n}=6)$ or live-stranded $(n=1)$, with right whales quickly killed by vessels $(n=5)$ and healthy right whales $(\mathrm{n}=113)$ to characterize fGC responses to acute vs. chronic stressors. fGCs in entangled whales (mean \pm SE: $1856.4 \pm 1644.9 \mathrm{ng} \mathrm{g}^{-1}$ ) and the stranded whale $\left(5740.7 \mathrm{ng} \mathrm{g}^{-1}\right.$ ) were significantly higher than in whales killed by vessels $\left(46.2 \pm 19.2 \mathrm{ng} \mathrm{g}^{-1}\right)$ and healthy whales $\left(51.7 \pm 8.7 \mathrm{ng} \mathrm{g}^{-1}\right)$. Paired feces and serum collected from the live-stranded right whale provided comparison of fGCs in 2 matrices in a chronically stressed whale. Serum cortisol and corticosterone in this whale $(50.0$ and $29.0 \mathrm{ng} \mathrm{ml}^{-1}$, respectively) were much higher than values reported in other cetaceans, in concordance with extremely elevated fGCs. Meaningful patterns in fGC concentration related to acute vs. chronic impacts persisted despite potential for bacterial degradation of hormone metabolites in dead whales. These results provide biological validation for using fGCs as a biomarker of chronic stress in NARWs.
\end{abstract}

KEY WORDS: North Atlantic right whale - Stress - Glucocorticoids - Fecal hormones · Entanglement

\section{INTRODUCTION}

As escalating human activities continue to alter marine ecosystems, there is increasing concern about deleterious impacts on marine mammal populations (reviewed by Pompa et al. 2011, Davidson et al. 2012, McCauley et al. 2015). Entanglement in commercial

${ }^{*}$ Corresponding author: rrolland@neaq.org fishing gear and vessel strikes cause significant mortality of large whales (Cassoff et al. 2011, van der Hoop et al. 2015), particularly in coastally distributed North Atlantic right whales Eubalaena glacialis (hereafter NARW), whose extant population numbers less than 500 individuals (Pace et al. 2017). It is even more challenging to assess the sub-lethal impacts of

(C) The authors 2017. Open Access under Creative Commons by Attribution Licence. Use, distribution and reproduction are unrestricted. Authors and original publication must be credited. 
anthropogenic stressors on individuals or populations (Tyack 2008, Fleishman et al. 2016, Rolland et al. 2016, Williams et al. 2016). Concern about the non-lethal effects of human activities has resulted in the development of methods to quantify physiological and pathological responses of non-captive marine mammals (Ayres et al. 2012, Rolland et al. 2012, Hunt et al. 2014a, Kellar et al. 2015). In this regard, measurement of glucocorticoid hormones is the most widely applied approach to assess the physiological impacts of anthropogenic factors in both marine and terrestrial wildlife, and is used as an indicator of the overall health of individuals and populations (Wikelski \& Cooke 2006, Bonier et al. 2009, Dickens \& Romero 2013, Dantzer et al. 2014).

Within minutes of experiencing an actual or perceived stressor (i.e. environmental, physical, or perceptual factors that disrupt homeostasis), glucocorticoid hormones (GCs; cortisol and corticosterone) are released by the adrenal cortex into the bloodstream as part of the neuroendocrine stress response in vertebrates, which is mediated by the hypothalamicpituitary-adrenal axis (Wingfield \& Romero 2001, Romero \& Butler 2007). These steroid hormones are secreted in response to a wide variety of natural (e.g. aggression, predator avoidance, food shortage, extreme weather events) and anthropogenic factors (e.g. noise and habitat disturbance; Sapolsky et al. 2000, Wasser et al. 2000, Keay et al. 2006, Atkinson et al. 2015). The primary physiological effect of GCs is the mobilization of energetic resources to allow the animal to respond to whatever challenge is present. Over a short time frame (hours/days), this stress response is beneficial and can be life-saving; however, chronic elevations of GCs (weeks/months) become maladaptive and may result in decreased growth, depressed immune system function, and suppression of reproduction (Boonstra et al. 1998, Sapolsky et al. 2000, Romero \& Wikelski 2001, Romero \& Butler 2007, Busch \& Hayward 2009).

Traditional approaches to measure circulating steroid hormones are not currently feasible for freeswimming, large whales that cannot be safely captured to collect blood samples. However, methods to measure steroid hormones using alternative matrices (i.e. feces, respiratory vapor, baleen, blubber) have been recently developed for whales (Mansour et al. 2002, Rolland et al. 2005, Hunt et al. 2006, 2014a,b, Hogg et al. 2009, Ayres et al. 2012, Kellar et al. 2013). Measurement of fecal GCs (hereafter fGCs) has been used for decades for stress assessment in terrestrial wildlife, and more recently in marine mammals (reviewed by Keay et al. 2006, Amaral 2010, Atkinson et al. 2015). Circulating GCs are extensively metabolized in the liver and excreted with bile, and these fecal metabolites can be quantified using immunoassays (see Wasser et al. 2000). Concentrations of fGCs reflect both baseline levels of free GCs in blood (i.e. unbound to corticosteroid-binding globulin), and elevations in response to stressors, providing a valuable tool for stress assessment in wildlife (Busch \& Hayward 2009, Sheriff et al. 2010). Fecal sampling is non-invasive, providing a distinct advantage over methods requiring capture and handling, which elicit a stress response within minutes. Additionally, fGCs represent an integrative measure of the average level of circulating GCs (without diurnal or pulsatile fluctuations), making this sampling strategy ideal for evaluating chronic stress responses (Dickens \& Romero 2013, Dantzer et al. 2014). The temporal pattern of hormones in feces is determined primarily by gastrointestinal transit time for the species under study (Palme et al. 2005, Goymann 2012); in NARWs it has been estimated that fecal hormones reflect blood levels 1-2 d before sample collection (Rolland et al. 2005). Immunoassay of fGCs has been used to quantify stress responses in NARWs (Hunt et al. 2006, Rolland et al. 2012) and southern resident killer whales Orcinus orca (Ayres et al. 2012).

Several authors have emphasized the importance of adequate physiological and biological validations for non-invasive hormone research because the identity of the metabolite being quantified, and its relationship to the biologically active form of the hormone, are usually unknown (Palme et al. 2005, Touma \& Palme 2005, Sheriff et al. 2010, 2011, Goymann 2012). The lack of a controlled experimental setting or a captive model makes the classic physiological validation of glucocorticoid assays (e.g. adrenocorticotropic hormone stimulation or dexamethasone suppression tests) impossible in large, free-swimming whales. However, for well-studied populations with identifiable individuals and longitudinal life history data such as NARWs, biological validation is possible by comparing hormone concentrations to patterns expected for different physiological states (Rolland et al. 2005, 2007). For example, pregnant right whales have highly elevated fecal progestagens (i.e. metabolites of progesterone) consistent with the endocrine characteristics of this life history stage (Rolland et al. 2005). Hunt et al. (2006) showed that fGCs in NARWs varied predictably with sexual maturity and reproductive status; pregnant females and mature males had physiologically normal elevations of fGCs, as would be expected. The latter study also included a single case showing highly elevated fGCs in a 
NARW (no. 1102) with a chronic, fatal fishing gear entanglement, providing evidence for a direct relationship between fGCs and the debilitated state of the whale.

In this study, we compared fGC concentrations in healthy NARWs to whales subjected to anthropogenic factors resulting in a chronic decline in health leading to death (fishing gear entanglement, livestranding) or a rapid death (vessel strike). We tested the prediction that whales killed by vessels died too rapidly for increases in fGCs to be detected, while chronic impacts including fishing gear entanglement and live-stranding would result in significantly elevated fGCs. The objectives of this study were to: (1) characterize baseline fGC concentrations by demographic group in a large dataset of identified, healthy right whales; (2) determine the relationship between fGC concentration and duration of the impact or injury by comparing fGC levels in right whales killed by vessel strike (acute stressor), severely entangled, or live-stranded (chronic stressors) to fGC levels in healthy right whales; (3) compare fGC concentration in paired serum and fecal samples obtained from a live-stranded right whale to examine concordance of hormone concentrations in these 2 matrices; and (4) investigate whether all of these results support the validity of fGCs as a readily obtainable biomarker of adrenal activation reflecting a physiological stress response in NARWs.

\section{MATERIALS AND METHODS}

\section{Whale identification and life history data}

Photographs of sampled right whales were compared to images in the NARW Identification Database (Hamilton et al. 2007; rwcatalog.neaq.org), and life history data were obtained from the North Atlantic Right Whale Consortium (2016a) databases. Individual whales were identified using the unique pattern of callosities on their head, lips, and chin (i.e. raised, roughened patches of skin colonized by cyamid whale lice), pigmentation, and scars (Kraus et al. 1986). When the identity of the sampled whale was not definite, a combination of photographed whale sightings, hormone profiles, and molecular profiling (i.e. mitochondrial haplotype, microsatellite profiles) was used to associate fecal samples with individual whales, using criteria described by Gillett et al. (2010) and Doucette et al. (2012). Whales were classified by age following Hamilton et al. (1998): calves $<1 \mathrm{yr}$; juveniles $1-8 \mathrm{yr}$; adults $\geq 9 \mathrm{yr}$ (or the year before first calving in females). Extensive survey effort in the NARW calving ground and other habitats enabled identification of the vast majority of calving females, allowing for determination of reproductive status in adult females as either pregnant, lactating, or resting (i.e. non-pregnant, non-lactating) (Browning et al. 2010, Rolland et al. 2016).

\section{Fecal samples from healthy right whales}

Floating fecal samples were collected opportunistically from NARWs during photo-identification surveys of spring and summer habitats (1999-2014), and with the assistance of scent detection dogs (Rolland et al. 2005, 2006). Fecal material was scooped from the water surface using a $300 \mu \mathrm{m}$ mesh nylon dip net (Sea-Gear) attached to an extendable boathook, stored in polypropylene jars (without preservatives) at $-20^{\circ} \mathrm{C}$ until the end of the field season, and archived at $-80^{\circ} \mathrm{C}$ until analysis (see Rolland et al. 2005 for details). Samples were collected throughout the NARW range, extending from the southeastern US winter calving grounds to summer habitats off Nova Scotia, Canada.

Fecal samples from apparently healthy, photoidentified NARWs with known life history data were used to characterize baseline fGCs. 'Healthy right whales' were defined as whales without active fishing gear entanglements, evidence of recent trauma, or any visible indication of compromised health when the sample was collected. Of 385 fecal samples collected, $144(37.4 \%)$ were linked to identified NARWs. Samples from calves and unknown age or sex whales were excluded; results from duplicate samples were averaged (i.e. 2 separate samples collected from a single defecation). Data from pregnant females were included only if pregnancy was independently confirmed by multiple subsequent sightings with an attendant calf. The analyses presented here incorporated fGC data from NARWs of known sex, age-class, and reproductive state $(\mathrm{n}=113)$, which were categorized into 6 demographic groups for analyses: juvenile male; mature male; juvenile female; resting female; pregnant female; or lactating female.

\section{Fecal and serum samples from injured and dead right whales}

Twelve fecal samples from right whales severely impacted by anthropogenic factors were included in 
this study: live-stranded $(\mathrm{n}=1)$; fatally entangled in fishing gear $(n=6)$; and killed by vessel strike $(n=5$; Table 1). Cause of death was determined by detailed gross and microscopic examination of the carcasses (Moore et al. 2004, 2007, 2013). Cases ranged in age from 2 to $30+y r$, and included both sexes and 2 pregnant females (Table 1).

Right whale no. 3710, a juvenile male, was beached alive for at least $3 \mathrm{~d}$ on a sandbar offshore of Cape Lookout, North Carolina (Harms et al. 2014). This stranding was considered to be secondary to a severe vertebral deformity (caudal scoliosis) caused by a previous fishing gear entanglement. Prior to euthanasia of this whale, a blood sample was collected from the fluke vessels via a dorsal approach (Harms et al. 2014) into a serum-separator tube (BD Vacutainer SST ${ }^{\mathrm{TM}}$, Becton, Dickinson and Company), and a fecal sample was collected from the colon. The blood sample was kept cool during transport to the laboratory, where it was centrifuged to harvest serum $\sim 3.5 \mathrm{~h}$ after collection. Frozen serum was shipped overnight on icepacks to the New England Aquarium (NEAq, Boston, MA) laboratory and archived $\left(-80^{\circ} \mathrm{C}\right)$ until assay.

Fecal samples from dead and living entangled right whales were collected (1999-2012) from the rectum during necropsy, or scooped from the water surface during attempts by disentanglement teams to remove the fishing gear (nos. 3911 and 1102; Table 1). Fecal samples were frozen $\left(-20^{\circ} \mathrm{C}\right)$ after collection without preservatives, and archived $\left(-80^{\circ} \mathrm{C}\right)$ until assay. Two fecal samples were collected from entangled right whale no. 3911; the first sample was obtained while the whale was still alive (Fig. 1), and the second sample was collected at necropsy $18 \mathrm{~d}$ later. For the remaining 4 entangled whales, fecal samples were collected at necropsy. In all cases, death was caused by cachexia, debilitation, infection, sepsis, and/or exsanguination directly related to the entanglement (Right Whale Consortium 2016a). The maximum duration of entanglement ranged from 306-1816 d, based on the last sighting of the whale before entanglement until the date of sample collection (or death). When it could be determined (i.e. the whale was not dead at the first entangled sighting), the minimum entanglement duration was 38-719 d from the first entangled sighting to sample collection or death.

Four of the 5 vessel strike cases died rapidly, based on gross necropsy and histopathology results showing massive ante-mortem blunt trauma. The fifth case (no. 1014) had histological evidence of initial cellular repair to a mandibular fracture, suggesting that the whale may have survived at least 7-10 d after the initial traumatic injury (North Atlantic Right Whale Consortium 2016b).

\section{Fecal sample processing and immunoassay}

Fecal samples were processed and extracted as previously described (Rolland et al. 2005, Hunt et al. 2006). Briefly, samples were thawed and mixed thoroughly, and a subsample was freeze-dried under

Table 1. Fecal glucocorticoid (fGC) metabolite concentrations $\left(\mathrm{ng} \mathrm{g}^{-1}\right.$ ) in North Atlantic right whales Eubalaena glacialis (NARW) that were live-stranded, entangled in fishing gear, or killed by vessel strike. The date is the day of fecal sample collection, location is the abbreviation for the US state (NC: North Carolina; MA: Massachusetts; FL: Florida; DE: Delaware) or Canadian province (NS: Nova Scotia) where the sample was collected. Demographic groups, JM: juvenile male; AM: adult male; JF: juvenile female; AF: adult female; PF: pregnant female. For dead whales, tissue condition is the score assigned to the carcass at necropsy on a 5-point scale (higher is worse) based on the degree of tissue decomposition. For the living entangled whales, visually assessed body condition is assigned as good, fair, or poor (Pettis et al. 2004)

\begin{tabular}{|c|c|c|c|c|c|c|}
\hline NARW no. & Date & Location & Impact & $\begin{array}{c}\text { Demographic } \\
\text { group }\end{array}$ & $\begin{array}{c}\mathrm{fGC} \\
\left(\mathrm{ng} \mathrm{g}^{-1}\right)\end{array}$ & $\begin{array}{c}\text { Tissue/body } \\
\text { condition }\end{array}$ \\
\hline 3710 & 30 Jan 2009 & $\mathrm{NC}$ & Live stranded & JM & 5740.7 & 1 \\
\hline 1102 & 14 July 2001 & MA & Live entangled & $\mathrm{AM}$ & 178.3 & Poor \\
\hline 3911 & 15 Jan 2011 & FL & Live entangled & $\mathrm{JF}$ & 146.7 & Fair to poor \\
\hline 1124 & 1 July 2010 & $\mathrm{DE}$ & Dead entangled & $\mathrm{AM}$ & 10070.4 & 3 \\
\hline 1113 & 15 Aug 2010 & NS & Dead entangled & AM & 103.4 & 4 \\
\hline 3911 & 3 Feb 2011 & FL & Dead entangled & $\mathrm{JF}$ & 611.9 & 1 \\
\hline 4193 & 19 Dec 2012 & FL & Dead entangled & $J M$ & 27.9 & $3+$ \\
\hline 1014 & 21 April 1999 & MA & Dead vessel strike & $\mathrm{AF}$ & 12.6 & $3+$ \\
\hline 2150 & 5 Oct 2003 & NS & Dead vessel strike & $\mathrm{AF}$ & 19.3 & 4 \\
\hline 1004 & 11 Feb 2004 & $\mathrm{NC}$ & Dead vessel strike & $\mathrm{PF}$ & 111.7 & 3 \\
\hline 1909 & 24 Nov 2004 & $\mathrm{NC}$ & Dead vessel strike & $\mathrm{PF}$ & 68.1 & 3 \\
\hline 2617 & 29 April 2005 & MA & Dead vessel strike & $\mathrm{AF}$ & 19.5 & $3+$ \\
\hline
\end{tabular}




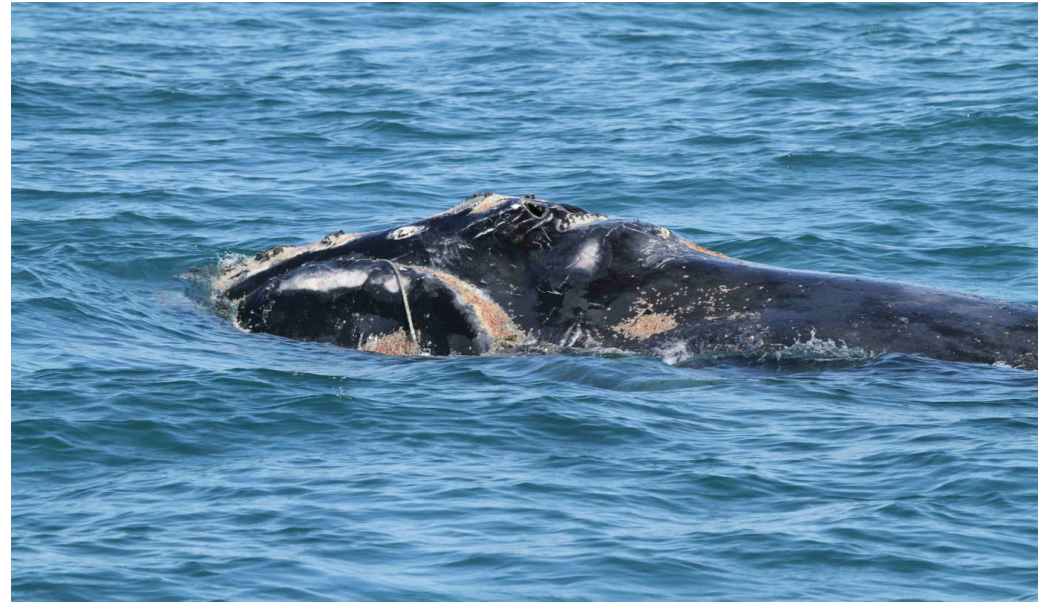

Fig. 1. A chronically entangled North Atlantic right whale Eubalaena glacialis (no. 3911, 'Bayla') photographed on 15 January 2011 during an attempt to disentangle the whale when a fecal sample was collected for hormone analysis. Fishing line can be seen exiting the lower jaw. Evidence of seriously compromised health includes: poor body condition, white skin lesions, patches of orange cyamids, and rake marks forward of the blowholes (Pettis et al. 2004). Fecal glucocorticoid metabolites were 8 times higher in this whale compared to healthy right whales of the same sex and age class. Photo is courtesy of Georgia Department of Natural Resources, taken under NOAA Permit No. 932-1905/MA-009526

vacuum for $7 \mathrm{~d}$ (or until dry). Two aliquots of dry powder were weighed to the nearest $0.2000 \pm$ $0.0001 \mathrm{~g}$ ('A' and 'B' extracts), mixed with $2.00 \mathrm{ml}$ of $90 \%$ methanol, vortexed for $30 \mathrm{~min}$, and centrifuged for $20 \mathrm{~min}$ at $4000 \times \mathrm{g}$, and each supernatant was pipetted into a cryovial. After chilling overnight at $-20^{\circ} \mathrm{C}$, extracts were spun using a mini-centrifuge and decanted into a new cryovial to remove fecal particulates. Fecal extracts were then diluted 1:4 in assay buffer (steroid diluent no. 07199196, MP Biomedicals). This sample dilution was calculated (based on previous validations for this species) to achieve near $50 \%$ binding on the standard curve (the point of greatest assay accuracy).

Immunoassays for fGCs were previously validated for NARW feces using parallelism and accuracy tests (Hunt et al. 2006). The glucocorticoid assay was a double-antibody ${ }^{125}$ I radioimmunoassay kit (corticosterone kit no. 07-120103, MP Biomedicals); the manufacturer's protocol was followed except that the assay was performed at half-volume. This assay uses an antibody raised against corticosterone, but it also detects fecal cortisol metabolites in a wide range of species including marine mammals (Wasser et al. 2000). For further assay details and antibody crossreactivity, see Hunt et al. (2006). The units reported for fecal hormones are ng of immunoreactive hormone per $\mathrm{g}$ of dried fecal powder $\left(\mathrm{ng} \mathrm{g}^{-1}\right)$. All sam- ples from 1999-2005 were analyzed within 6 mo of collection; samples from 2006-2011 were analyzed in late 2011, and samples from 2012-2014 were assayed in 2015. Studies have shown that fecal hormone metabolites remain relatively stable for years when samples are kept frozen (Hunt \& Wasser 2003).

Standard quality assurance/quality control procedures were used (Grotjan \& Keel 1996, Ezan \& Grassi 2000), including assay of non-specific binding tubes and zero-dose tubes in quadruplicate, and assay of all standards (6 standards spanning 0.125$\left.5.00 \mathrm{ng} \mathrm{ml}^{-1}\right)$, controls $(\sim 30$ and $\sim 70 \%$ binding), and samples in duplicate. Samples with coefficients of variation (CV) between duplicates $>10 \%$ or binding outside $10-90 \%$ on the standard curve, were re-diluted and reassayed. The 'A' and ' $\mathrm{B}$ ' fecal extracts were analyzed in separate assays with final results averaged. If hormone concentrations in the 2 extracts (from the same sample) had CVs $>20 \%$, new dilutions were produced and assayed again. Finally, any sample with anomalous results was re-assayed to confirm results. Inter- and intra-assay CVs for corticosterone assays were $<10 \%$ in the NEAq laboratory.

\section{Serum hormone validation studies and immunoassays}

Collection of a blood sample from a NARW is a rare event; therefore, immunoassays for serum GCs in the live-stranded whale (no. 3710) required validation because there were no previously published methods. The predominant type of circulating corticosteroid in right whales was unknown, so we compared 2 antibodies (cortisol and corticosterone) for their capacity to detect glucocorticoids in NARW serum, following recommendations of Grotjan \& Keel (1996) and Ezan \& Grassi (2000). In preparation for both assays, serum (1:1 un-extracted) was vortexed thoroughly, and diluted 1:2 in dissociation reagent (no. X017, Arbor Assays) to yield the total corticosteroid concentration in serum. For analysis of cortisol, this solution was further diluted in cortisol assay buffer to 1:10 (no. X053, EIA assay buffer, Arbor Assays) and then serially-diluted (by halving) to 1:1280 for the 
parallelism test. The cortisol assay was a commercial enzyme immunoassay (EIA; no. K003-H1, Arbor Assays) run following the manufacturer's protocol. For corticosterone, the sample solution (serum diluted 1:2 in dissociation reagent) was diluted to $1: 10$ in corticosterone assay buffer (no. 07-166197, MP Biomedicals), then serially-diluted in the same buffer (1:10 to 1:320) for parallelism tests. Samples were assayed with MP Biomedicals ${ }^{125}$ I corticosterone assay (no. 07-120103), which was performed at half the volume in the manufacturer's protocol, and with an additional low-dose standard added to the standard curve (i.e. $0.0625 \mathrm{ng} \mathrm{ml}^{-1}$ ), produced by mixing equal volumes of the lowest standard $\left(0.125 \mathrm{ng} \mathrm{ml}^{-1}\right)$ and corticosterone assay buffer.

To test parallelism, the slope of percent-bound vs. log (relative dose) of the serum sample was compared to a curve of known-dose hormone standards (cortisol or corticosterone) run in the same assay. Parallelism of the linear portions of the 2 curves indicates that the serum hormone binds well to the assay antibody across a range of dilutions. Parallelism was analyzed using $F$-tests for equality of slope between the linear portions of the 2 curves (i.e. serially-diluted sample and standards). Statistical tests for the serum assay validations were performed using Prism 6 for Mac OSX. Final dilutions for immunoassays of the serum sample were 1:80 for cortisol and 1:30 for corticosterone. For additional details, including assay protocols, sensitivities, and antibody cross-reactivity, see Hunt et al. (2014b) for the cortisol assay and Hunt et al. (2006) for the corticosterone assay. The results are reported as ng $\mathrm{ml}^{-1}$ of un-extracted serum.

\section{Statistical analysis of fGCs}

Standard descriptive statistics (mean, median, standard error of the mean [SE]) were used to characterize (non-transformed) fGC concentrations. Hormone data were transformed $\left(\log _{10}\right)$ for the following analyses to meet assumptions of normality and homogeneity of variance, which were tested using a Shapiro-Wilk test and Levene's test. To characterize the influence of life history stage on hormone values, fGCs in the 6 demographic groups (categorized by sex, age class, and reproductive state; see Table 2 for groups) were compared using a 1-way analysis of variance (ANOVA) with a post hoc Tukey test to identify group differences. fGC data from healthy and injured or dead NARWs were analyzed in a general linear model (GLM) framework (normal errors and an identity link function), with the aim of de- scribing and explaining the stress response of NARWs to anthropogenic injury of varying durations (acute vs. chronic). The explanatory variables included in the model were categorical, and characterized aspects of the injury experienced by the whale (duration of impact, alive or dead at time of sampling) as well as demographic group of the sampled whale. The duration of impact variable had 3 factor levels, which included a reference category of healthy whales (i.e. whales with no impact; $\mathrm{n}=113$ ), acute impact (i.e. whales struck by a vessel; $\mathrm{n}=5$ ), and chronic impact (i.e. whales severely injured by entanglement or live-stranded; $n=7$ ). Whale survival at the time of fecal sample collection was a binary variable (alive or deceased), which was included in the model to examine the potential influence of intestinal microbial alteration on fGC concentrations. Demographic group was included as a fixed effect in the model to account for known influences on fGC levels in NARWs (see 'Results'; Hunt et al. 2006). Factor levels for this variable were: juvenile male, adult male, juvenile female, resting female, lactating female, and pregnant female. An interaction term between the duration of impact and demographic group of the whale was also included in the model to investigate a potential relationship between this pair of explanatory variables and the response. The null hypothesis was no effect of the duration of the injury or impact on fGC concentration in NARWs. Differences between factor levels in the model were identified using $t$-statistics. Model assumptions were checked by visual inspection of residuals plotted against fitted values and Q-Q plots to ensure validity of the model estimates (Quinn \& Keough 2002). Analyses were based on the assumption that the samples from individual whales in this study (although small for some factors) were representative of the variability in fGC concentrations in this population. These statistical analyses were conducted using IBM SPSS ${ }^{\circledR}$ statistical software (version 20 for Macintosh). Results were considered significant at $\mathrm{p}<0.05$.

\section{RESULTS}

\section{fGCs in healthy right whales}

Descriptive statistics for fGC concentration categorized by demographic group are reported in Table 2. The transformed $\left(\log _{10}\right)$ fGC data for all groups met the assumptions of normality (Shapiro-Wilk test, $\mathrm{p}=$ 0.054), and homogeneity of variance (Levene's test, $\mathrm{p}=0.506)$. There was a statistically significant dif- 
Table 2. Mean ( \pm SE) and median fecal glucocorticoid (fGC) levels $\left(\mathrm{ng} \mathrm{g}^{-1}\right)$ in healthy North Atlantic right whales Eubalaena glacialis categorized by sex, age class, and reproductive status, and in whales severely impacted by live-stranding (single value), chronic entanglement in fishing gear, and rapidly fatal vessel strikes. The entanglement data include whales sampled at necropsy and while living, including 2 results from whale no. 3911 that was sampled once while alive and again at necropsy (see Table 1). Mean fGC concentrations in the healthy whales with the same superscript letter were not significantly different (Tukey test, $\mathrm{p}>0.05$ ). fGCs in the live-stranded and chronically entangled whales were significantly higher than in healthy whales, while fGCs in whales killed by vessel strike were not different from those of healthy whales (see 'Results' for details)

\begin{tabular}{|llcc|}
\hline Sex (n) & $\begin{array}{c}\text { Age class/status } \\
(\mathrm{n})\end{array}$ & $\begin{array}{c}\text { Mean fGC } \\
( \pm \mathrm{SE})\end{array}$ & $\begin{array}{c}\text { Median } \\
\text { fGC }\end{array}$ \\
\hline Healthy whales & & \\
Female (75) & Juvenile (20) & $18.2 \pm 1.7^{\mathrm{a}}$ & 16.2 \\
& Resting (17) & $19.1 \pm 3.1^{\mathrm{a}}$ & 15.3 \\
& Lactating (25) & $38.6 \pm 4.1^{\mathrm{c}, \mathrm{d}}$ & 29.8 \\
& Pregnant (13) & $181.0 \pm 64.4^{\mathrm{e}}$ & 94.6 \\
Male (38) & Juvenile (16) & $26.0 \pm 2.8^{\mathrm{a}, \mathrm{c}}$ & 22.1 \\
& Adult (22) & $64.5 \pm 7.1^{\mathrm{d}, \mathrm{e}}$ & 64.0 \\
Live-stranded/entangled/vessel strike (12) & \\
& Live-stranded (1) & 5740.7 & - \\
& Entangled (6) & $1856.4 \pm 1644.9$ & 162.5 \\
& Vessel strike (5) & $46.2 \pm 19.2$ & 19.5 \\
\hline
\end{tabular}

ference between fGCs in healthy whales according to demographic group as determined by 1-way ANOVA $\left(F_{5,107}=23.47, \mathrm{p}<0.001\right.$; Table 2, Fig. 2$)$. A Tukey post hoc test showed that pregnant females had significantly higher fGCs than all other groups (mean \pm SE: $181.0 \pm 64.4 \mathrm{ng} \mathrm{g}^{-1}, \mathrm{p}=0.001$ ) except for

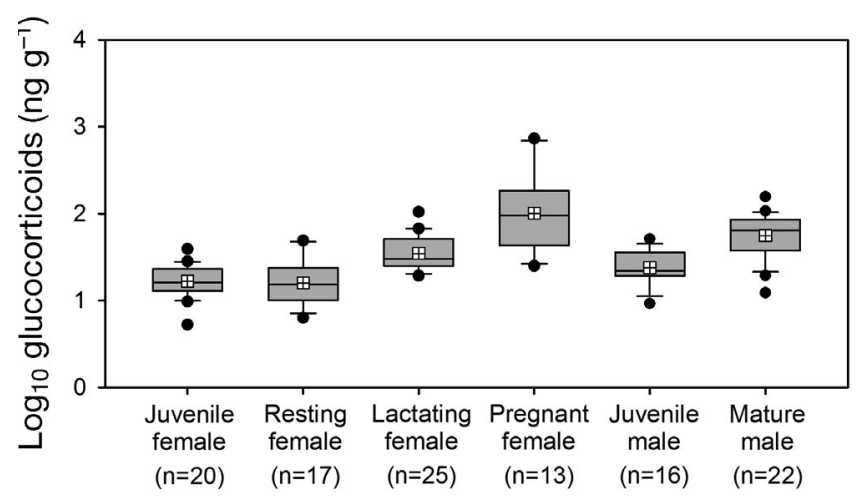

Fig. 2. Fecal glucocorticoids $\left(\log _{10}\right)$ in healthy North Atlantic right whales Eubalaena glacialis categorized by sex, age class, and reproductive state. Horizontal lines within the boxes show median values, the small hatched boxes depict mean values, whiskers show the variability outside the upper and lower quartiles, and filled circles are outliers. Significant differences between groups are shown in Table 2 adult males $\left(64.5 \pm 7.1 \mathrm{ng} \mathrm{g}^{-1}, \mathrm{p}=0.059\right)$. fGC levels were significantly higher in lactating females (38.6 \pm $4.1 \mathrm{ng} \mathrm{g}^{-1}$ ) compared to juvenile females (18.2 \pm $\left.1.7 \mathrm{ng} \mathrm{g}^{-1}, \mathrm{p}=0.001\right)$, but not juvenile males $(26.0 \pm$ $\left.2.8 \mathrm{ng} \mathrm{g}^{-1}, \mathrm{p}=0.366\right)$ or adult males $(\mathrm{p}=0.089)$. There were no differences in fGC concentrations between juvenile females, juvenile males $(p=0.497)$, or resting females $\left(19.1 \pm 3.1 \mathrm{ng} \mathrm{g}^{-1}, \mathrm{p}=1.000\right)$, or between juvenile males and resting females $(p=0.401)$. These variations in fGC concentrations across different demographic groups were in close agreement with patterns previously reported for this species (Hunt et al. 2006). The fGC concentration for healthy whales in all demographic groups combined was $51.7 \pm$ $8.7 \mathrm{ng} \mathrm{g}^{-1}$.

\section{fGCs in NARWs in response to acute vs. chronic anthropogenic impacts}

fGC concentrations in NARWs were significantly influenced by the duration of the impact experienced by the whale (GLM: $F_{3,113}=21.085, \mathrm{p}<0.001$ ), and the overall model explained $58 \%$ of the variance in the fGC data $\left(R^{2}=0.579\right)$. Results showed significant elevation of fGC concentrations in whales that had experienced chronic anthropogenic injuries or impacts (Table 3), including live-stranding (5740.7 ng $\mathrm{g}^{-1}$ ) and fatal entanglement in fishing gear (mean \pm SE: $1856.4 \pm 1644.9 \mathrm{ng} \mathrm{g}^{-1}$; Table 2, Fig. 3). In contrast, fGC concentrations in whales killed by vessel strike $\left(46.2 \pm 19.2 \mathrm{ng} \mathrm{g}^{-1}\right)$ were similar to fGCs in healthy whales (Table 2, Fig. 3). As reported above, fGC levels varied between demographic groups (Table 2); however, there was no interaction effect on fGC concentration between demographic group and the duration of impact or injury $\left(F_{3,113}=0.197, \mathrm{p}=\right.$

Table 3. Summary results of the general linear model for fecal glucocorticoid concentrations of North Atlantic right whales Eubalaena glacialis in response to the duration of the anthropogenic injury or impact, and whether the fecal sample was collected while the whale was alive or after death

\begin{tabular}{|c|c|c|c|c|c|}
\hline $\begin{array}{l}\text { Para- } \\
\text { meter }\end{array}$ & $\begin{array}{l}\text { Coefficient } \\
\text { estimate }\end{array}$ & $\mathrm{SE}$ & $t$ & $\mathrm{p}$ & $\begin{array}{c}\text { Observed } \\
\text { power }\end{array}$ \\
\hline Intercept & 1.746 & 0.071 & 24.656 & $<0.001$ & 1.000 \\
\hline \multicolumn{6}{|c|}{ Impact duration (baseline: healthy) } \\
\hline Acute & -0.064 & 0.252 & -0.253 & 0.801 & 0.057 \\
\hline Chronic & 1.147 & 0.267 & 4.299 & $<0.001$ & 0.989 \\
\hline \multicolumn{6}{|c|}{ Survival at sample collection (baseline: alive) } \\
\hline Deceased & -0.205 & 0.257 & -0.796 & 0.428 & 0.124 \\
\hline
\end{tabular}




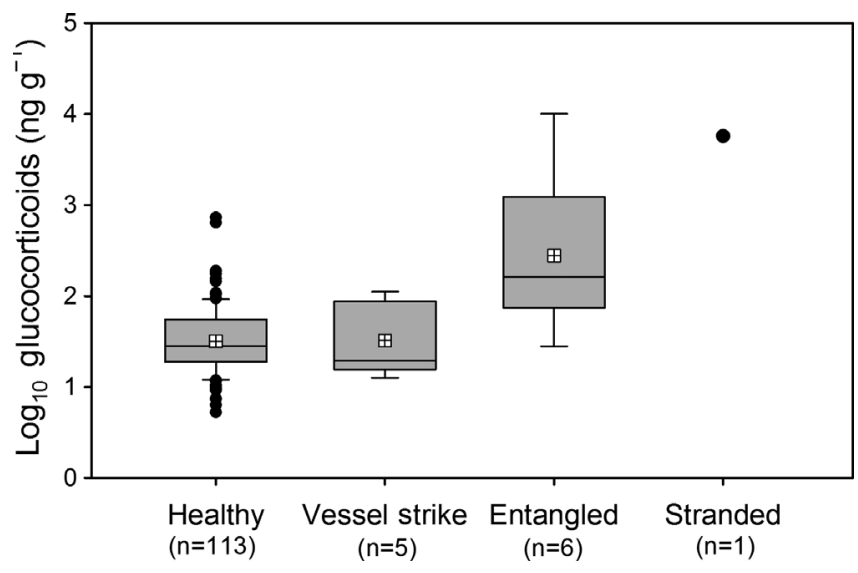

Fig. 3. Fecal glucocorticoid concentrations $\left(\log _{10}\right)$ in healthy North Atlantic right whales Eubalaena glacialis compared to right whales killed by vessel strike, fatally entangled in fishing gear, or live-stranded. The horizontal line within the boxes shows median values, means are indicated by the small hatched box, whiskers show the variability outside the upper and lower quartiles, and outliers are shown as filled circles

0.899). Finally, whether a whale was sampled while alive or dead did not contribute to variation in fGC concentrations among whales $\left(F_{1,113}=0.633, \mathrm{p}=\right.$ 0.428; Table 3).

\section{Paired fecal and serum glucocorticoids in a live-stranded right whale}

Both GC assays had detectable hormone in serum over a range of dilutions, and the serially-diluted sample curves were parallel to the standard curves for both assays (cortisol, $F_{1,10}=0.931, \mathrm{p}=0.357$; corticosterone, $F_{1,8}=0.731, \mathrm{p}=0.417$; Fig. 4 ). Both cortisol and corticosterone were present in serum from the live-stranded whale $\left(50.0,29.0 \mathrm{ng} \mathrm{ml}^{-1}\right.$, respectively), with cortisol predominating. fGCs measured in this whale (5740.7 $\mathrm{ng} \mathrm{g}^{-1}$ ) were several orders of magnitude higher than baseline levels in healthy whales (Table 2, Fig. 3). Although based on serum and fGC data from a single whale, these results support the conclusion that this biomarker reflects adrenal cortical activation secondary to extreme physiological stress in a freshly collected (i.e. non-degraded) sample.

\section{DISCUSSION}

This study found significant elevations of fGCs in NARWs chronically entangled in fishing gear or livestranded, compared to healthy living right whales and whales that died rapidly from vessel strikes. Because there is a time lag between increases in circulating GCs and the appearance of higher concentrations of GC metabolites in feces, whales that died rapidly after a vessel strike presumably did not survive long enough for a stress response to be detectable in feces. Although bacterial alteration of hormone metabolites is a concern for interpretation of samples from dead whales (Palme et al. 2005, Goymann 2012), significant differences in fGC levels in whales with acute vs. chronic impacts show that meaningful patterns persisted in most cases that reflected the time course of mortality or injury. Further, fGCs were also elevated in 2 entangled whales that were sampled while alive, and fGCs in the livestranded whale were orders of magnitude higher

(a) Cortisol

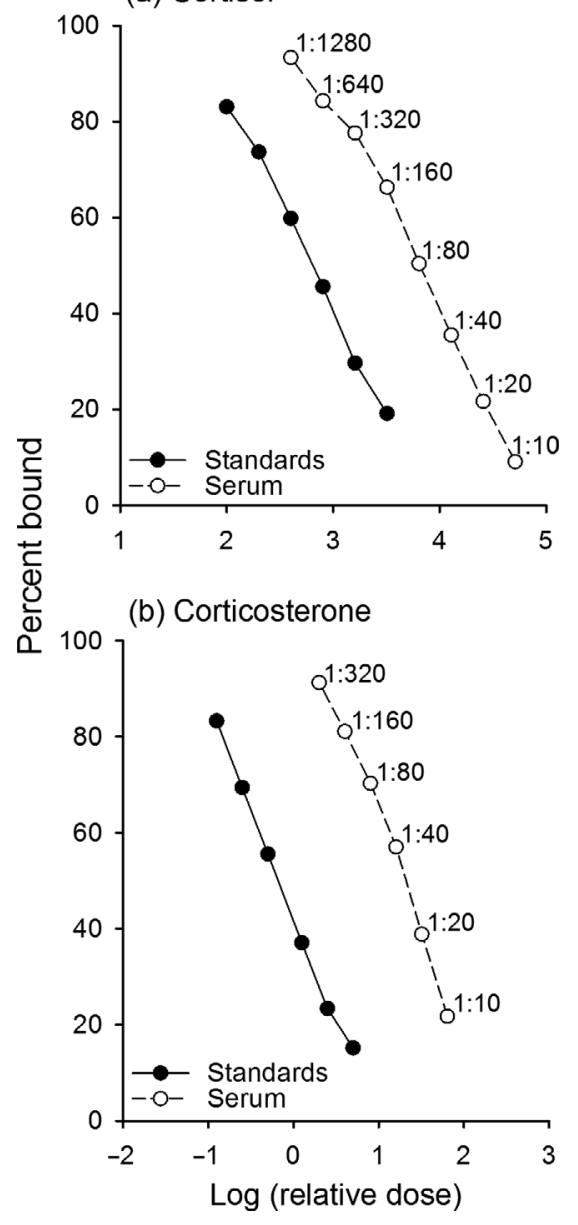

Fig. 4. Parallelism results for (a) cortisol and (b) corticosterone assays using serum collected from a live-stranded North Atlantic right whale Eubalaena glacialis (no. 3710). Note similar slopes for the serially-diluted samples (open circles with dashed lines) compared to known-dose hormone standards (closed circles with solid lines) showing successful parallelism for both glucocorticoid assays 
than baseline levels. In sum, these results confirm that fGC concentrations reflected a strong adrenal stress response in NARWs impacted by severe, chronic physical challenges. This approach could also provide insight into the time course to death in cases where the proximate cause of mortality is unclear, including carcasses that cannot be recovered for a full necropsy ('floaters'), if a fecal sample can be obtained.

The predominant circulating GC in the livestranded NARW (no. 3710) was cortisol, although corticosterone was also present in appreciable concentrations. These are the first data on circulating hormones in NARW to our knowledge, and the relative proportion of serum GCs was undoubtedly influenced by the extreme stress experienced by this whale. Thus, the serum hormone profile in a healthy right whale would be expected to be different. The serum hormone results presented here are total GCs (i.e. free + bound, due to use of the dissociation reagent), and the levels of free (unbound) physiologically active hormone were not determined. Circulating cortisol in this highly stressed whale was an order of magnitude higher than baseline values reported in other cetaceans, which usually encompass a narrow range of concentrations (see Table 5 in St. Aubin \& Dierauf 2001). It was also higher than cortisol levels reported in most cetaceans subjected to capture stress, although methodological differences may invalidate direct comparisons (Thomson \& Geraci 1986, Orlov et al. 1991, St. Aubin et al. 1996, Suzuki et al. 1998, 2003, Kjeld 2001, St. Aubin 2001, Schmitt et al. 2010, Fair et al. 2014, Hart et al. 2015). Stranded whales experience gradual respiratory and cardiovascular collapse (without their neutral buoyancy in seawater), along with blistered skin, hyperthermia, and being scavenged on while alive (by gulls in this case), resulting in severe distress (Harms et al. 2014). Fecal GCs were elevated by several orders of magnitude in NARW no. 3710 compared to baseline, suggesting that the free-GC serum hormone concentrations were also highly elevated, since fGCs reflect an integrated measure of the unbound circulating hormone (Sheriff et al. 2010, Breuner et al. 2013). Although based only on the data from a single whale, these results show correspondence of hormone concentrations in 2 matrices in a severely distressed whale.

The baseline hormone concentrations in healthy NARWs reported here confirm the findings of an earlier study (Hunt et al. 2006) with almost double the sample size of identified whales, demonstrating the robustness and consistency of this approach for quantification of fGCs in NARWs. Whales killed rapidly by vessel strikes did not have elevated fGCs compared to healthy whales. Histological evidence of a healing mandibular fracture in NARW no. 1014 suggested that this whale survived for at least $1 \mathrm{wk}$ after the vessel collision, probably long enough for elevated GCs to be detected in feces, yet fGC concentrations were not high (Table 1). Busch \& Hayward (2009) presented evidence that stress responses can be non-linear and hard to predict depending on the time course of the response. They suggested a log-quadratic model, such that early, adaptive adrenal responses to a stressor can be within the baseline range, and GC levels can also decrease again to 'normal' ranges later in the stress response after reaching a plateau. Therefore, abnormally low GCs can be pathological in certain circumstances, indicating adrenal exhaustion, or an equivalent failure of physiological mechanisms that permit an organism to respond to severe stressors. For example, common bottlenose dolphins Tursiops truncatus in the northern Gulf of Mexico exposed to oil from the Deepwater Horizon spill had low circulating concentrations of both cortisol and aldosterone, and very thin adrenal cortices were seen histologically (Schwacke et al. 2014, Venn-Watson et al. 2015). NARW no. 1014 was in very poor health at her last sighting before death, and had pathological findings at necropsy including chronic papillomatous skin lesions and extensive ulceration of the glossal mucosa. Therefore, it is possible that this whale was so severely debilitated that she was unable to maintain a stress response (note that the viscera were too autolyzed for examination of the adrenal glands).

Five of 6 entangled whales had obviously elevated fGCs, suggesting severe physiological impacts from these chronic entanglements. The fGC concentration in NARW no. 3911 while alive (146.7 $\mathrm{ng} \mathrm{g}^{-1}$; Fig. 1) was 8 times higher than baseline levels for corresponding healthy juvenile females $\left(18.2 \pm 1.7 \mathrm{ng} \mathrm{g}^{-1}\right)$. fGC levels more than quadrupled in the second sample collected from this whale post mortem $18 \mathrm{~d}$ later (611.9 $\mathrm{ng} \mathrm{g}^{-1}$; Table 1), reflecting a drastic deterioration in health. The average duration for fatal entanglements in this population is $6 \mathrm{mo}$, with some whales carrying fishing gear for years before death (Moore \& van der Hoop 2012). The suffering experienced by whales that die slowly from the effects of entanglement has been deemed an animal welfare issue (Moore et al. 2006, Moore \& van der Hoop 2012, Moore 2014), and this assertion is supported by the highly elevated fGCs in most chronically entangled whales in this study. The sixth entangled whale did 
not have increased fGCs (no. 4193, Table 1). The necropsy report concluded this whale died of malnourishment caused by an entanglement that interfered with mobility, and fishing gear trauma in the oral cavity likely interfered with feeding. As a result, there was little digesta in the colon, and a very small fecal sample was obtained only by scraping the wall of the colon. Therefore, it is very likely that this was not an adequate sample to get an accurate measure of fGCs, emphasizing caution when interpreting fecal hormone data from low-mass samples (Hayward et al. 2010).

The major causes of injury and mortality in NARWs result from overlap with human activities in the oceans. Over $50 \%$ of mortalities have been caused by vessel strikes and fishing gear entanglements (Kraus et al. 2005, van der Hoop et al. 2015), and $83 \%$ of this population bear scars from non-lethal encounters with commercial fishing gear (Knowlton et al. 2012). Recovery of the NARW population will require significant reductions in the anthropogenic causes of mortality (Kraus et al. 2005, 2016). In addition, slow population growth, evidence of declining whale health, and low calving rates strongly suggest that other factors, including the sub-lethal effects of human disturbance, are also having significant impacts on this species (Rolland et al. 2012, 2016, van der Hoop et al. 2017).

The current study creates a solid foundation for assessing the physiological impacts of sub-lethal disturbance in NARWs by characterizing baseline fGC concentrations in healthy whales, and providing biological validation of the link between elevated fGCs and chronic stress in this species. Elevated fGCs in 2 living, entangled whales in this study indicate that endocrine assessments can be applied to evaluate the impact of sub-lethal entanglements. Significant increases in fGCs have been found in NARWs exposed to underwater noise from large vessels (Rolland et al. 2012), further supporting this approach for assessing the effects of different injurious or potentially impactful events experienced by NARWs. Fecal hormone analysis can be expanded to incorporate other endocrine biomarkers such as aldosterone, another indicator of adrenal activation, and thyroid hormones, which provide information on nutritional status and metabolic state (Atkinson et al. 2015). These hormone data could be incorporated into modeling approaches to estimate the impacts of different stressors on both individuals and populations (e.g. Schick et al. 2013, Fleishman et al. 2016, Rolland et al. 2016). Thus, quantification of physiological responses to various anthropogenic stressors can be used to evaluate sub-lethal effects, and should be considered a valuable tool to assess the impacts of human activities on marine wildlife.

Acknowledgements. Our special gratitude to the NE and SE U.S. Marine Mammal Stranding Networks, and the necropsy and disentanglement teams for their extraordinary efforts on behalf of NARWs. Many thanks to the Right Whale Research Team at the NEAq and numerous other scientists and assistants who have collected samples since 1999 for this research. We greatly appreciate the thoughtful comments from 4 anonymous reviewers, Scott Kraus, and Katherine Graham, who also provided assistance with graphics. We are grateful to the members of the North Atlantic Right Whale Consortium for data-sharing approval and for embracing a collaborative approach that has greatly benefited right whale research and conservation. This research was funded by the NOAA/NMFS, Office of Naval Research Marine Mammals and Biology Program, Northeast Consortium, Island Foundation, Irving Oil, NEAq Internal Research Fund, Prescott Grant NA08NMF4390590, and NOAA CINAR Cooperative Agreement NA09OAR4320129. Fieldwork was conducted under NOAA Scientific Research Permits 1014, 655-1652, and 14233 issued to Scott D. Kraus, and Canadian Foreign Fishing/Research Licenses and Species at Risk Permits from the Department of Fisheries and Oceans, issued to Scott D. Kraus and Moira W. Brown. All field research with right whales was approved by the NEAq IACUC. Right whale necropsies and disentanglement efforts were conducted under NOAA Permits 932-1905-MA009526, 932-1489-05 issued to Dr. Theresa Rowles and 9321489 to the Center for Coastal Studies, and in Canada under permits issued by the Department of Fisheries and Oceans.

\section{LITERATURE CITED}

Amaral RS (2010) Use of alternative matrices to monitor steroid hormones in aquatic mammals: a review. Aquat Mamm 36:162-171

Atkinson S, Crocker D, Houser D, Mashburn K (2015) Stress physiology in marine mammals: How well do they fit the terrestrial model? J Comp Physiol B 185:463-486

Ayres KL, Booth RK, Hempelmann JA, Koski KL and others (2012) Distinguishing the impacts of inadequate prey and vessel traffic on an endangered killer whale (Orcinus orca) population. PLOS ONE 7:e36842

* Bonier F, Martin PR, Moore IT, Wingfield JC (2009) Do baseline glucocorticoids predict fitness? Trends Ecol Evol 24: 634-642

* Boonstra R, Hik D, Singleton GR, Tinnikov A (1998) The impact of predator-induced stress on the snowshoe hare cycle. Ecol Monogr 68:371-394

* Breuner CW, Delehanty B, Boonstra R (2013) Evaluating stress in natural populations of vertebrates: Total CORT is not good enough. Funct Ecol 27:24-36

Browning CL, Rolland RM, Kraus SD (2010) Estimated calf and perinatal mortality in western North Atlantic right whales (Eubalaena glacialis). Mar Mamm Sci 26:648-662

Busch DS, Hayward LS (2009) Stress in a conservation context: a discussion of glucocorticoid actions and how levels change with conservation-relevant variables. Biol Conserv 142:2844-2853 
Cassoff RM, Moore KM, McLellan WA, Barco SG, Rotstein DS, Moore MJ (2011) Lethal entanglement in baleen whales. Dis Aquat Org 96:175-185

* Dantzer B, Fletcher QE, Boonstra R, Sheriff MJ (2014) Measures of physiological stress: a transparent or opaque window into the status, management and conservation of species? Conserv Physiol 2:cou23

Davidson AD, Boyer AG, Kim H, Pompa-Mansilla S and others (2012) Drivers and hotspots of extinction risk in marine mammals. Proc Natl Acad Sci USA 109:3395-3400

Dickens MJ, Romero LM (2013) A consensus endocrine profile for chronically stressed wild animals does not exist. Gen Comp Endocrinol 191:177-189

* Doucette GJ, Mikulski CM, King KL, Roth PB and others (2012) Endangered North Atlantic right whales (Eubalaena glacialis) experience repeated, concurrent exposure to multiple environmental neurotoxins produced by marine algae. Environ Res 112:67-76

Ezan E, Grassi J (2000) Optimization. In: Gosling JP (ed) Immunoassays: a practical approach. Oxford University Press, Oxford, p 187-210

Fair PA, Schaefer AM, Romano TA, Bossart GD, Lamb SV, Reif JS (2014) Stress response of wild bottlenose dolphins (Tursiops truncatus) during capture-release health assessment studies. Gen Comp Endocrinol 206:203-212

Fleishman E, Costa DP, Harwood J, Kraus S and others (2016) Monitoring population-level responses of marine mammals to human activities. Mar Mamm Sci 32: 1004-1021

Gillett RM, Frasier TR, Rolland RM, White BN (2010) Molecular identification of individual North Atlantic right whales (Eubalaena glacialis) using free-floating feces. Mar Mamm Sci 26:917-936

Goymann W (2012) On the use of non-invasive hormone research in uncontrolled, natural environments: the problem with sex, diet, metabolic rate and the individual. Methods Ecol Evol 3:757-765

Grotjan HE, Keel BA (1996) Data interpretation and quality control. In: Diamandis EP, Christopoulos TK (eds) Immunoassay. Academic Press, San Diego, CA, p 51-95

Hamilton PK, Knowlton AR, Marx MK, Kraus SD (1998) Age structure and longevity in North Atlantic right whales Eubalaena glacialis and their relation to reproduction. Mar Ecol Prog Ser 171:285-292

Hamilton PK, Knowlton AR, Marx MM (2007) Right whales tell their own stories: the photo-identification catalog. In: Kraus SD, Rolland RM (eds) The urban whale: North Atlantic right whales at the crossroads. Harvard University Press, Cambridge, MA, p 75-104

Karms CA, McLellan WA, Moore MJ, Barco SG, Clarke EO III, Thayer VG, Rowles TK (2014) Low-residue euthanasia of stranded mysticetes. J Wildl Dis 50:63-73

Hart LB, Wells RS, Kellar N, Balmer BC and others (2015) Adrenal hormones in common bottlenose dolphins (Tursiops truncatus): influential factors and reference intervals. PLOS ONE 10:e0127432

Hayward LS, Booth RK, Wasser SK (2010) Eliminating the artificial effect of sample mass on avian fecal hormone metabolite concentration. Gen Comp Endocrinol 169: $117-122$

*Hogg CJ, Rogers TL, Shorter A, Barton K, Miller PJO, Nowacek D (2009) Determination of steroid hormones in whale blow: It is possible. Mar Mamm Sci 25:605-618

*Hunt KE, Wasser SK (2003) Effect of long-term preservation methods on fecal glucocorticoid concentrations of grizzly bear and African elephant. Physiol Biochem Zool 76: 918-928

Hunt KE, Rolland RM, Kraus SD, Wasser SK (2006) Analysis of fecal glucocorticoids in the North Atlantic right whale (Eubalaena glacialis). Gen Comp Endocrinol 148: 260-272

*Hunt KE, Rolland RM, Kraus SD (2014a) Detection of steroid and thyroid hormones via immunoassay of North Atlantic right whale (Eubalaena glacialis) respiratory vapor. Mar Mamm Sci 30:796-809

Hunt KE, Stimmelmayr R, George C, Hanns C, Suydam R, Brower H Jr, Rolland RM (2014b) Baleen hormones: a novel tool for retrospective assessment of stress and reproduction in bowhead whales (Balaena mysticetus). Conserv Physiol 2:cou030

Keay JM, Singh J, Gaunt MC, Kaur T (2006) Fecal glucocorticoids and their metabolites as indicators of stress in various mammalian species: a literature review. J Zoo Wildl Med 37:234-244

* Kellar NM, Keliher J, Trego ML, Catelani KN, Hanns C, George JC, Rosa C (2013) Variation of bowhead whale progesterone concentrations across demographic groups and sample matrices. Endang Species Res 22:61-72

Kellar NM, Catelani KN, Robbins MN, Trego ML, Allen CD, Danil K, Chivers SJ (2015) Blubber cortisol: a potential tool for assessing stress response in free-ranging dolphins without effects due to sampling. PLOS ONE 10: e0115257

Kjeld M (2001) Concentrations of electrolytes, hormones, and other constituents in fresh postmortem blood and urine of fin whales (Balaenoptera physalus). Can J Zool 79:438-446

Knowlton AR, Hamilton PK, Marx MK, Pettis HM, Kraus SD (2012) Monitoring North Atlantic right whale Eubalaena glacialis entanglement rates: a $30 \mathrm{yr}$ retrospective. Mar Ecol Prog Ser 466:293-302

Kraus SD, Moore KE, Price CA, Crone MJ, Watkins WA, Winns HE, Prescott JH (1986) The use of photographs to identify individual North Atlantic right whales (Eubalaena glacialis). Rep Int Whal Comm Spec Issue 10: 145-151

Kraus SD, Brown MW, Caswell H, Clark CW and others (2005) North Atlantic right whales in crisis. Science 309: 561-562

Kraus SD, Kenney RD, Mayo CA, McLellan WA, Moore MJ, Nowacek DP (2016) Recent scientific publications cast doubt on North Atlantic right whale future. Front Mar Sci 3:137

Mansour AAH, Mkay DW, Lien J, Orr JC, Banoub JH, Ølen N, Stenson G (2002) Determination of pregnancy status from blubber samples in minke whales (Balaenoptera acutorostrata). Mar Mamm Sci 18:112-120

* McCauley DJ, Pinsky ML, Palumbi SR, Estes JA, Joyce FH, Warner RR (2015) Marine defaunation: animal loss in the global ocean. Science 347:1255641

Moore MJ (2014) How we all kill whales. ICES J Mar Sci 71: 760-763

Moore MJ, van der Hoop JM (2012) The painful side of trap and fixed net fisheries: chronic entanglement of large whales. J Mar Biol 2012:230653

Moore MJ, Knowlton AR, Kraus SD, McLellan WA, Bonde RK (2004) Morphometry, gross morphology and available histopathology in North Atlantic right whale (Eubalaena glacialis) mortalities (1970-2002). J Cetacean Res Manag $6: 199-214$ 
Moore MJ, Bogomolni A, Bowman R, Hamilton PK and others (2006) Fatally entangled right whales can die extremely slowly. In: OCEANS 2006. IEEE, Washington, DC

Moore MJ, McLellan WA, Daoust PY, Bonde RK, Knowlton AR (2007) Right whale mortality: a message from the dead to the living. In: Kraus SD, Rolland RM (eds) The urban whale: North Atlantic right whales at the crossroads. Harvard University Press, Cambridge, MA, p 358-379

Moore MJ, van der Hoop J, Barco SG, Costidis AM and others (2013) Criteria and case definitions for serious injury and death of pinnipeds and cetaceans caused by anthropogenic trauma. Dis Aquat Org 103:229-264

North Atlantic Right Whale Consortium (2016a) North Atlantic Right Whale Consortium Identification Database 08/19/2016. New England Aquarium, Boston, MA

North Atlantic Right Whale Consortium (2016b) North Atlantic Right Whale Consortium Necropsy Database 08/19/2016. New England Aquarium, Boston, MA

Orlov MV, Mukhlya AM, Kuz'min AA (1991) Hormonal and electrolyte changes in cetacean blood after capture and during experimental stress. J Evol Biochem Physiol 27: 197-205

Pace RM III, Corkeron PJ, Kraus SD (2017) State space estimates reveal a recent decline in abundance of North Atlantic right whales. Ecol Evol 7:8730-8741

*Palme R, Rettenbacher S, Touma C, El-Bahr S, Möstl E (2005) Stress hormones in mammals and birds: comparative aspects regarding metabolism, excretion, and noninvasive measurement in fecal samples. Ann NY Acad Sci 1040:162-171

* Pettis HM, Rolland RM, Hamilton PK, Brault S, Knowlton AR, Kraus SD (2004) Visual health assessment of North Atlantic right whales (Eubalaena glacialis) using photographs. Can J Zool 82:8-19

* Pompa S, Ehrlich PR, Ceballos G (2011) Global distribution and conservation of marine mammals. Proc Natl Acad Sci USA 108:13600-13605

Quinn GP, Keough MJ (2002) Experimental design and data analysis for biologists. Cambridge University Press, Cambridge

Rolland RM, Hunt KE, Kraus SD, Wasser SK (2005) Assessing reproductive status of right whales (Eubalaena glacialis) using fecal hormone metabolites. Gen Comp Endocrinol 142:308-317

Rolland RM, Hamilton PK, Kraus PK, Davenport B, Gillett RM, Wasser SK (2006) Faecal sampling using detection dogs to study reproduction and health in North Atlantic right whales (Eubalaena glacialis). J Cetacean Res Manag 8:121-125

Rolland RM, Hunt KE, Doucette GJ, Rickard LG, Wasser SK (2007) The inner whale: hormones, biotoxins and parasites. In: Kraus SD, Rolland RM (eds) The urban whale: North Atlantic right whales at the crossroads. Harvard University Press, Cambridge, MA, p 232-272

Rolland RM, Parks SE, Hunt KE, Castellote M and others (2012) Evidence that ship noise increases stress in right whales. Proc R Soc Lond B Biol Sci 279:2363-2368

Rolland RM, Schick RS, Pettis HM, Knowlton AR, Hamilton PK, Clark JS, Kraus SD (2016) Health of North Atlantic right whales Eubalaena glacialis over three decades: from individual health to demographic and population health trends. Mar Ecol Prog Ser 542:265-282

Romero ML, Butler LK (2007) Endocrinology of stress. Int J
Comp Psychol 20:89-95

* Romero LM, Wikelski M (2001) Corticosterone levels predict survival probabilities of Galápagos marine iguanas during El Niño events. Proc Natl Acad Sci USA 98: 7366-7370

Sapolsky RM, Romero LM, Munck AU (2000) How do glucocorticoids influence stress responses? Integrating permissive, suppressive, stimulatory, and preparative actions. Endocr Rev 21:55-89

Schick RS, Kraus SD, Rolland RM, Knowlton AR and others (2013) Using hierarchical Bayes to understand movement, health, and survival in the endangered North Atlantic right whale. PLOS ONE 8:e64166

Schmitt TL, St Aubin DJ, Schaefer AM, Dunn JL (2010) Baseline, diurnal variations, and stress-induced changes of stress hormones in three captive beluga whales, Delphinapterus leucas. Mar Mamm Sci 26:635-647

Schwacke LH, Smith CR, Townsend FI, Wells RS and others (2014) Health of common bottlenose dolphins (Tursiops truncatus) in Barataria Bay, Louisiana, following the Deepwater Horizon oil spill. Environ Sci Technol 48: 93-103

* Sheriff MJ, Krebs CJ, Boonstra R (2010) Assessing stress in animal populations: Do fecal and plasma glucocorticoids tell the same story? Gen Comp Endocrinol 166:614-619

* Sheriff MJ, Dantzer B, Delehanty B, Palme R, Boonstra R (2011) Measuring stress in wildlife: techniques for quantifying glucocorticoids. Oecologia 166:869-887

St. Aubin D (2001) Endocrinology. In: Dierauf LA, Gulland FMD (eds) CRC handbook of marine mammal medicine, 2nd edn. CRC Press, Boca Raton, FL, p 165-192

St. Aubin D, Dierauf LA (2001) Stress and marine mammals. In: Dierauf LA, Gulland FMD (eds) CRC handbook of marine mammal medicine, 2nd edn. CRC Press, Boca Raton, FL, p 253-269

* St. Aubin D, Ridgway SH, Wells R, Rhinehart H (1996) Dolphin thyroid and adrenal hormones: circulating levels in wild and semidomesticated Tursiops truncatus, and influence of sex, age, and season. Mar Mamm Sci 12:1-13

* Suzuki M, Tobayama T, Katsumata E, Yoshioka M, Aida K (1998) Serum cortisol levels in captive killer whale and bottlenose dolphin. Fish Sci 64:643-647

* Suzuki M, Uchida S, Ueda K, Tobayama T, Katsumata E, Yoshioka M, Aida K (2003) Diurnal and annual changes in serum cortisol concentrations in Indo-Pacific bottlenose dolphins Tursiops aduncus and killer whales Orcinus orca. Gen Comp Endocrinol 132:427-433

* Thomson C, Geraci J (1986) Cortisol, aldosterone, and leucocytes in the stress response of bottlenose dolphins, Tursiops truncatus. Can J Fish Aquat Sci 43:1010-1016

Touma C, Palme R (2005) Measuring fecal glucocorticoid metabolites in mammals and birds: the importance of validation. Ann N Y Acad Sci 1046:54-74

* Tyack P (2008) Implications for marine mammals of largescale changes in the marine acoustic environment. J Mammal 89:549-558

van der Hoop JM, Vanderlaan AS, Cole TV, Henry AG and others (2015) Vessel strikes to large whales before and after the 2008 ship strike rule. Conserv Lett 8:24-32

*van der Hoop JM, Corkeron P, Moore M (2017) Entanglement is a costly life-history stage in large whales. Ecol Evol 7:92-106

*Venn-Watson S, Colegrove KM, Litz J, Kinsel M and others (2015) Adrenal gland and lung lesions in Gulf of Mexico common bottlenose dolphins (Tursiops truncatus) found 
dead following the Deepwater Horizon oil spill. PLOS ONE 10:e0126538

Wasser SK, Hunt KE, Brown JL, Cooper K and others (2000) A generalized fecal glucocorticoid assay for use in a diverse array of non-domestic mammalian and avian species. Gen Comp Endocrinol 120:260-275

Wikelski M, Cooke SJ (2006) Conservation physiology. Trends Ecol Evol 21:38-46

Williams R, Thomas L, Ashe E, Clark CW, Hammond PS

Editorial responsibility: Helene Marsh, Townsville, Queensland, Australia
(2016) Gauging allowable harm limits to cumulative, sub-lethal effects of human activities on wildlife: a casestudy approach using two whale populations. Mar Policy 70:58-64

Wingfield JC, Romero LM (2001) Adrenocortical responses to stress and their modulation in free-living vertebrates. In: McEwen BS, Goodman HM (eds) Handbook of physiology: the endocrine system. Oxford University Press, New York, NY, p 211-234

Submitted: September 15, 2016; Accepted: September 29, 2017 Proofs received from author(s): November 17, 2017 